\title{
The Correlation between Bullying and Students Learning Achievement in SMP Negeri 6 Kota Gorontalo
}

\author{
Rhein Djunaid,*, Eka Pratiwi Puluhulawa, and Muh. Nur Syukriani Yusuf \\ School Of Nursing, University of Gorontalo State, Indonesia \\ *Correspondence: riansyahdjunaid@gmail.com \\ Type of the Paper (Article) \\ Received: September 3, 2019; Accepted: October 1, 2019; Published: October 30, 2019 \\ https://doi.org/10.29253/achnr.2019.1539
}

\begin{abstract}
Objective: Bullying that occurs in a school environment is violence that causes other students to suffer and is perpetrated by a stronger student or a group of students and over and over. thus affecting victims, social behavior, and learning achievement. The study aims at investigating the correlation between bullying and students' learning achievement in SMP Negeri 6 Kota Gorontalo. Methods: descriptive study with a cross-sectional study approach. The population was students of class V II. The research sample was 83 students who were selected through simple random sampling. Results: The findings show that 68 respondents experienced bullying and 115 respondents did not experience bullying. 22 respondents have low learning achievement, and 161 respondents have good learning achievement. There is a relationship between learning and student achievement in SMP Negeri 6 Gorontalo City with a probability value of 0.000 (p $<0.05)$. Conclusion: it is hoped that the school can increase understanding regarding the bully phenomenon and its concern for the disposed activities that occur in the school environment.
\end{abstract}

Keywords: bullying; school; achievement; learning

\section{Introduction}

World Health Organization (WHO) explains that adolescents (adolescents) are those aged between 10-19 years. At this age adolescents will experience a critical period where they must adjust to various changes both in biological and psychological aspects that have become the demands of the task of adolescent development. These changes can affect adolescent behavior both in health, social behavior, and can even lead to deviant behavior or often known as bullying (Agustiani, 2006). Bullying is aggressive behavior that is undesirable by other children which can result in repetitive physical, psychological or social damage, which often occurs in schools and other places where children gather, including social media (WHO, 2019). Bullying is an act of suppressing or intimidating other children both physically and verbally and usually there is an imbalance of power between the perpetrators and victims of bullying (Lee, Chun, Kim, \& Lee, 2020)

A study conducted by the NGO Plan International and the International Center for Research on Women (ICRW) released at the beginning of March 2015 also showed astonishing facts related to child 
abuse in schools. At the Asian level, the incidence of bullying among students in schools reaches 70\%. This study also states that $84 \%$ of students in Indonesia experience violence in schools (Qodar, 2015).

The Indonesian Child Protection Commission (KPAI) notes that from 2011-2014 there were 369 complaints regarding bullying. The number is around $25 \%$ of the total complaints in the education sector as many as 1,480 cases. Bullying referred to by KPAI as a form of violence in schools, defeats student brawls, educational discrimination, or complaints of extortion (Republika, 2014).

In Gorontalo Province itself, not a few cases of violence occurred in schools. Some reports reported by the Gorontalo Post newspaper were cases of beatings by teachers to students which resulted in the students fainting. Another case that occurred was a case of beating by a teacher of seven students using wood on the calf until it was bruised. In other schools, there were also cases of violence received by students from their teachers, which made the students skip school (Gorontalo Post, 2016, 2017, 2018). With reporting about cases of violence in the school, did not rule out the possibility of similar behavior among students who are not yet known. The Semai Jiwa Amini Foundation (SEJIWA, 2008) explains that adolescents who receive pressure will display symptoms such as fear, anxiety, depression, low selfesteem, and worthlessness. Decreased self-confidence can result in social behavior where they tend not to socialize with their environment. In addition, adolescents who are victims of bullying will have less interest in going to school, it is difficult to think clearly so that his academic achievements can be threatened to decline.

Academic achievement or better known as learning achievement is one indicator of success in the learning process that can be influenced by various factors. Slameto (2010) explains that there are internal factors such as physical, psychological and fatigue conditions. In addition, there are also external factors such as the family environment, community environment, and school environment. Bullying that occurs in the school environment can influence children's motivation and interest in achieving learning achievement. This is supported by research conducted by Ida Ayu Surya Dwipayanti and Komang Rahayu Indrawati in 2014, regarding "The Relationship Between Bullying Actions and Learning Achievement of Bullying Victims Children at Elementary School Level" found that there was a relationship between bullying acts and bullying learning achievements of children victims of bullying .

\section{Method}

This research was conducted in Gorontalo City 6 Public Middle School in March 2018 with a descriptive analytic research design using a cross sectional approach. The population in this study were all students of class VIII which were then selected as samples through a simple random sampling technique of 183 students. Data collection techniques were used to measure the scale of bullying experience using one questionnaire and to see student achievement using the average value of odd semester report cards.

\section{Analysis Technique}

In conducting the analysis, especially the research data will use the help of the SPSS computer program. 1. Univariate Analysis

Univariate analysis aims to describe the characteristics of each research variable. In general, this analysis only uses the distribution and percentage of each variable. The independent variable, namely bullying, and the dependent variable, namely learning achievement, were analyzed by presenting the results obtained (Notoatmodjo, 2012).

\section{Bivariate Analysis}

Bivariate analysis aims to determine the relationship between the independent variable, namely bullying, and the dependent variable, namely achievement learning (Notoatmodjo, 2012). In this study, the statistical test used was the chi square using the SPSS (Statistical Product and Service Solution) computer program. 


\section{Results}

\subsection{Student bullying experience}

Table 1. Distribution of respondents based on bullying's experience.

\begin{tabular}{clrr}
\hline No Experience Bullying & Value (n) & Frequency (\%) \\
\hline 1 & Do Not Experience & 115 & 62.9 \\
2 & Experience & 68 & 37.1 \\
Total & $\mathbf{1 8 3}$ & $\mathbf{1 0 0 . 0}$
\end{tabular}

Source: Primary data 2018

Table 1 shows the distribution of respondents based on bullying experience. It can be seen that respondents who did not experience bullying were 115 respondents (62.8\%) and those who experienced bullying were 68 respondents $(37.2 \%)$.

From the results of a study conducted on 183 respondents showed that respondents who did not experience bullying were 115 respondents (62.9\%) and those who experienced bullying were 68 respondents $(37.1 \%)$. The results of the questionnaire analysis used in assessing the experience of bullying respondents found the highest percentage of answer items often with a score of 'score 3' of 42\% and always with a value of 'score 4' of only $21 \%$ on positive statement items although for negative statement items the answers sometimes with a score of 'score 3 ' gets a percentage of $51 \%$ and always with a score of 'score 4 ' gets a percentage of $55 \%$.

\subsection{Student achievement}

Table 2. Distribution of respondents based on learning achievement.

\begin{tabular}{clrr}
\hline No Student Achievement & Value (n) & Frequency (\%) \\
\hline 1 Good & 161 & 88 \\
2 Poor & 22 & 12 \\
Total & $\mathbf{1 8 3}$ & $\mathbf{1 0 0}$
\end{tabular}

Source: Primary data 2018

Based on Table 2, the distribution of respondents based on learning achievement can be seen that respondents with good learning achievement totaling 161 respondents (88.0\%) and learning achievement less as many as 22 respondents (12.0\%).

Based on research conducted on 183 respondents of SMP Negeri 6 Gorontalo City, the results showed that there were 161 respondents (88\%) who had good learning achievement and 22 respondents (12\%) who had poor learning achievement. This can be seen from the average value of the criteria minimum completeness of each student where most respondents have a value of more than 75 which becomes the standard of KKM in schools.

\subsection{The relationship of bullying with student learning achievements in SMP Negeri 6 Gorontalo City}

Table 3. The relationship between bullying and student achievement at SMP Negeri 6 Gorontalo City.

\begin{tabular}{|c|c|c|c|c|c|c|c|c|}
\hline \multirow{2}{*}{ No } & \multirow{2}{*}{ Bullying } & \multicolumn{4}{|c|}{ Student Achievement } & \multirow{2}{*}{$\mathbf{n}$} & \multirow{2}{*}{$\%$} & \multirow{2}{*}{$\boldsymbol{\rho}$} \\
\hline & & Good & $\%$ & Less & $\%$ & & & \\
\hline 1 & Do not experience & 110 & 60.1 & 5 & 2.8 & 115 & 62.9 & 0.000 \\
\hline \multirow[t]{2}{*}{2} & Experience & 51 & 27.9 & 17 & 9.2 & 68 & 37.1 & 0.000 \\
\hline & Total & 161 & 88 & 22 & 12 & 183 & 100 & \\
\hline
\end{tabular}

Source: Primary data 2018 


\section{Discussion}

The data above shows the level of bullying that occurs in SMP Negeri 6 Gorontalo City is still low. The low bullying phenomenon that occurs in SMP Negeri 6 Gorontalo City can indicate that this school has tried to prevent the existence of bullying by maximizing counseling in schools. This is evidenced by the results of observations in the field found by researchers known that each grade level has a guidance counseling teacher who handles every problem of students in the school environment. This is supported by the theory revealed by Zakiyah, Humaedi, and Santoso (2017) that bullying can occur if supervision and ethical guidance from teachers is low, inappropriate guidance and inconsistent regulations. The results of this study are in line with research conducted by Usman in 2013 which showed a negative influence and significance between school climate on the incidence of bullying, which means the more positive the school climate built, the lower the incidence of bullying in it.

The results of this study indicate that of the 68 respondents included in the category of 'experiencing bullying' there were $66 \%$ of respondents who experienced psychological bullying. This indicates that psychological bullying is the most common type of bullying in SMP Negeri 6 Gorontalo City. This result is supported by a questionnaire analysis which shows that as many as $30 \%$ of respondents often receive unpleasant gazes and as many as 55\% of respondents have never been encouraged by people who have been enemies when they make mistakes.

Based on the results of statistical tests using chi square, it is known that the significance value of 0.000 . This P-value is still smaller than the alpha value used $(<0.05)$ so that the research hypothesis is accepted. Thus, it can be concluded that there is a relationship between bullying and student achievement in SMP Negeri 6 Gorontalo City.

The results showed that the higher the bullying experience experienced, the lower the learning achievement. This study is in line with research conducted by Ida Dwipayanti and Indrawati about the relationship between bullying and student achievement in bullying at the elementary school level which indicates that child victims of bullying will experience difficulties in getting along, feeling afraid of coming to school so that their absenteeism is high and lagging behind lessons, and having difficulty concentrating in following the lessons so that it will have an impact on their learning achievement. This is supported by the opinion of (Wiyani, 2012) that bullying that occurs in the school environment can reduce the enthusiasm for schooling, motivation and concentration in learning so that it affects the intelligence test scores and students' analytical skills which are indicators of learning achievement.

However, the results of this study are not in line with research conducted by Wulandari (2017) regarding the relationship of bullying behavior with learning achievement in adolescents in Gamping Muhammadiyah 2 Junior High School Sleman Yogyakarta which shows the results that there is no meaningful relationship between bullying behavior with the learning achievements of Muhammadiyah Middle School students 2 Gamping Sleman Yogyakarta. The difference in research results can be caused by differences in research locations, cultural support of the research site, the number of samples and the research methods used.

\section{Conclusion}

Based on the results of the discussion of the research conducted by researchers, it can be concluded that there are 68 respondents (37.1\%) who experienced bullying with the highest percentage for bullying that is often accepted by respondents is psychological bullying by $66 \%$. There are 22 respondents $(12 \%)$ with less learning achievement category where the average value of report cards is below the KKM (Minimum completeness criteria). There is a relationship between bullying with student achievement in SMP Negeri 6 Gorontalo City with a p-value of 0.000 .

\section{Acknowledgements}

For the nursing profession is expected to be able to recognize the symptoms of bullying victims and prevent the occurrence of bullying in adolescents so as to reduce the negative impact of the bullying incident itself. The next researcher is expected to be able to conduct deeper studies related to the phenomenon of bullying and acts of bullying received by victims and use the latest theories related to this phenomenon. In addition, it is also hoped that further researchers can control other variables that can affect learning achievement. The school is expected to pay more attention to bullying that occurs in 
the school environment and increase understanding related to the phenomenon of bullying that occurs to provide comfort for students who are in it.

\section{References}

Agustiani, H. (2006). Psikologi perkembangan: pendekatan ekologi kaitannya dengan konsep diri dan penyesuaian diri pada remaja. Bandung: Refika Aditama.

Lee, J., Chun, J., Kim, J., \& Lee, J. (2020). Cyberbullying victimisation and school dropout intention among South Korean adolescents: the moderating role of peer/teacher support. Asia Pacific Journal of Social Work and Development, 30(3), 195-211.

Notoatmodjo, S. (2012). Promosi kesehatan dan perilaku kesehatan. Jakarta: rineka cipta, 45-62.

Republika, (2014). Aduan Bullying Tertinggi. Republika. https://www.republika.co.id/berita/koran/halaman1/14/10/15/ndh4sp-aduan-bullying-tertinggi

Yayasan SEJIWA. (2018). Bullying : Mengatasi Kekerasan di Sekolah dan di Lingkungan Sekitar Anak. PT Grasindo.

Slameto. (2010). Belajar dan faktor-faktor yang mempengaruhinya. Rineka Cipta.

Qodar, N. (2015). Survei ICRW: 84\% anak Indonesia alami kekerasan di sekolah. Liputan6. Com.

WHO. (2019). School-based violence prevention: a practical handbook.

Wiyani, N. A. (2012). Desain Manajemen Pendidikan Karakter di Madrasah. INSANIA: Jurnal Pemikiran Alternatif Kependidikan, 17(1).

Wulandari, R. (2017). Pengaruh Penerapan Model Pembelajaraan Kooperatif Tipe Snowball Throwing Terhadap Hasil Belajar Ips Siswa Kelas Iv Sd Negeri 4 Metro Utara Tahun Pelajaran 2016/2017.

Zakiyah, E. Z., Humaedi, S., \& Santoso, M. B. (2017). Faktor yang mempengaruhi remaja dalam melakukan bullying. Prosiding Penelitian dan Pengabdian kepada Masyarakat, 4(2). 